\title{
Effect of VCO to leucocyte differential count, glucose levels and blood creatinine of hyperglycemic and ovalbumin sensitized Mus musculus Balb/c.
}

\author{
NOOR SOESANTI HANDAJANI ${ }^{1,3, \boldsymbol{v}}$, RUBEN DHARMAWAN ${ }^{2,3}$ \\ ${ }^{1}$ Department of Biology, Faculty of Mathematics and Natural Sciences, Sebelas Maret University. Jl. Ir. Sutami 36a Surakarta 57126, Central Java, \\ Indonesia. Tel./Fax.: +92-271-663375. ^email: noor_handajani@yahoo.com. \\ ${ }^{2}$ Faculty of Medicines, Sebelas Maret University, Surakarta 57126, Central Java, Indonesia \\ ${ }^{3}$ Bioscience Program, School of Graduates, Sebelas Maret University, Surakarta 57126, Central Java, Indonesia
}

Manuscript received: 3 December 2008. Revision accepted: 24 February 2009

\begin{abstract}
Handajani NS, Dharmawan R. 2009. Effect of VCO to leucocyte differential count, glucose levels and blood creatinine of hyperglycemic and ovalbumin sensitized Mus musculus Balb/c. Nusantara Bioscience 1: 1-8. Chemical medicines and insulin can decrease glucose blood levels in hyperglycemic patients with macrovascular side effects. The quality and quantity of leucocytes influence diabetes and allergy incidences. Lauric acid within VCO reports decreased glucose blood level of diabetes and some allergy incidents. The purpose of the study is to know the effect of VCO on the glucose blood level, differential leucocyte count, and creatinine blood level on hyperglycemic and normoglycemic ovalbumin-sensitized mice. Forty-five (45) males (mice) of Mus musculus Balb/c with an average weight of $35 \mathrm{~g}$ are divided into nine groups with five repetitions; those are four non-alloxan groups and five alloxaninduced hyperglycemic groups. From the $22^{\text {nd }}$ day to the $36^{\text {th }}$ day, they are sensitized to ovalbumin as an allergen. A blood sample was obtained by orbital vena using heparin as an anticoagulant to measure glucose blood level by GOD method to 6 times, on $1^{\text {st }}, 4^{\text {th }}, 18^{\text {th }}$, $22^{\text {nd }}, 32^{\text {nd, }}$ and $37^{\text {th }}$ days, then are tested by ANOVA followed by DMRT 0.05 . On the $37^{\text {th }}$ day, differential leucocytes are determined, the blood level is counted, and then compared to the normal value. This study showed that within differential leucocytes count of hyperglycemic mice, neutrophile percentage was much lower than the normal value (3.22\%), and lymphocyte percentage was much higher than the normal value (94.54\%). Consumed $0.003 \mathrm{~mL} / 35 \mathrm{~g}$ VCO more 18 days decreased glucose blood level on hyperglycemic mice, decreased basophile percentage of ovalbumin-sensitized mice, normalized neutrophile percentage no increased creatinine blood level.
\end{abstract}

Keywords: VCO, hyperglycemic, allergy, leucocytes differential count, blood creatinine.

\begin{abstract}
Abstrak. Handajani NS, Dharmawan R. 2009. Pengaruh VCO terhadap hitung jenis leukosit, kadar glukosa dan kreatinin darah Mus musculus Balb/c hiperglikemi dan tersensitisasi ovalbumin. Nusantara Bioscience 1: 1-8. Obat-obatan kimia dan insulin dapat menurunkan kadar glukosa darah pada pasien dengan efek samping hiperglikemi makro vaskular. Diabetes dan insiden alergi dipengaruhi kualitas dan kuantitas leukosit. Asam laurat dalam VCO dilaporkan menurunkan tingkat glukosa darah pada kejadian diabetes dan beberapa insiden alergi. Tujuan penelitian ini adalah mengetahui pengaruh VCO pada tingkat glukosa darah, diferensial leukosit dan kadar kreatinin pada mencit hiperglikemi dan normoglicemic tersensitisasi ovalbumin. Empat puluh lima (45) mencit Mus musculus Balb/c jantan dengan berat rata-rata $35 \mathrm{~g}$ dibagi menjadi 9 kelompok dengan 5 ulangan, yaitu 4 kelompok non aloksan dan 5 kelompok hiperglikemi yang diinduksi aloksan, Pada hari ke-22 sampai ke-36, mereka disensitisasi dengan ovalbumin sebagai penyebab alergi. Sampel darah diperoleh dari vena orbital menggunakan heparin sebagai anti koagulan, kadar glukosa darah diukur dengan metode GOD sebanyak 6 kali, pada hari ke-1, 4, 18, 22, 32 dan 37, kemudian diuji dengan ANAVA yang diikuti oleh DMRT 0,05 untk mengetahui tingkat perbedaan antar perlakuan. Pada hari ke-37, diferensial leukosit dan tingkat kreatinin darah ditentukan, lalu dibandingkan dengan nilai normal. Hasil penelitian menunjukkan bahwa dalam hitungan diferensial leukosit mencit hiperglikemi, persentase neutrofil jauh lebih rendah daripada nilai normal (3.22\%), dan persentase limfosit jauh lebih tinggi daripada nilai normal (94.54\%). Konsumsi $0.003 \mathrm{~mL} / 35 \mathrm{~g}$ VCO lebih dari 18 hari menurunkan kadar glukosa darah pada mencit hiperglikemi, menurunkan persentase basophile pada mencit tersensitisasi ovalbumin, normalisasi persentase neutrophile tidak meningkatkan tingkat kreatinin darah.
\end{abstract}

Kata kunci: VCO, hiperglikemia, alergi, hitungan diferensial leukosit, kreatinin darah.

\section{INTRODUCTION}

Diabetes mellitus is a disease of the pancreatic endocrine hormones, including insulin and glucagons. This was due to inadequate insulin activity. The amount of insulin secretion is reduced (Suharmiati 2003) or a response decrease in peripheral tissue to insulin (insulin resistance) and a reduction in the ability of pancreatic beta cells to secrete insulin in response to a glucose load. The main manifestations include disorders of lipid metabolism, carbohydrate, and protein, which stimulate the conditions of hyperglycemia. The state of hyperglycemia will develop into diabetes mellitus with various forms of complications manifestation (Unger and Foster 1992; Nugroho 2006). 
According to the UKPDS (1999), although sulfonylurea drugs and insulin can lower blood glucose levels, they can cause macrovascular problems. Because glucose is very important in lymphocyte metabolism, Diabetes can also cause characteristic changes in lymphocyte metabolism (Otton et al., 2002), stimulating lymphocyte apoptosis (Otton et al., 2004). Research by Alba-Loureiro et al. (2006) showed that diabetes also causes the characteristic of neutrophil function and metabolism of white rats.

Today, allergic is interpreted as an immunologic reaction to antigens unreasonably or inappropriately in individuals who the antigen in question has previously sensitized. The antigen is called an allergen. Ovalbumin, an allergenic protein found in a white egg, can often cause allergic reactions in children (Endaryanto and Harsono 1996). Two processes that mark the occurrence of the allergic process are exocytosed granule contents such as histamine and the induction of the formation of mediators that stimulate the formation of prostaglandins and leukotrienes that directly impact the local tissue (Kresno 2001).

All this time, the use of VCO (Virgin Coconut Oil) for cases of diabetes and allergies is empirically much done. Hence, the author wants to prove a reduction of blood glucose levels in hyperglycemia mice (Mus musculus $\mathrm{Balb} / \mathrm{c}$ ) with VCO treatment. Given the role of several types of leukocytes between the cases of diabetes and allergies, this study should also be noted that the VCO is potential for the vulnerability of normal and hyperglycemia mice on allergen exposure by viewing the leukocyte counts.

The consumption of nutritious substances that are expected to resolve a complaint needs to be watched out as the negative impacts may arise as a side effect. Therefore, it should be tested for the presence or absence of the rise of blood creatinine levels indicating the normality status of renal function physiologically, because the inability to excrete creatinine as a component of urine, so, in large numbers, it flows back into the bloodstream above its normal values.

Based on the background of the problems above, the purpose of this study are: (i) to examine the effect of VCO on blood glucose levels in mice (M. musculus) Balb/c hyperglycemia, (ii) to know the leukocyte counts of mice hyperglycemia, (iii) to investigate the VCO effect on leukocyte counts mice which are exposed to ovalbumin, (iv) the effect of VCO on leukocyte counts mice hyperglycemia which is exposed to ovalbumin, (v) the effect of VCO on levels of blood creatinine of mice in efforts to achieve normal glycemia conditions and protection against exposure to ovalbumin.

\section{MATERIALS AND METHODS}

\section{Time and place}

This research was conducted in October-November 2007. The Maintenance and the checking of blood sugar levels and creatinine in mice were conducted in LP3HPLPPT Gadjah Mada University, Yogyakarta.
Material

VCO is obtained from PT Prima Solutions Medika Jakarta, 45 mice (Mus musculus BaIb/c) 2-3 months old and male with an average body weight of $35 \mathrm{~g}$ are obtained from LP3HP-LPPT Gadjah Mada University, Yogyakarta. Alloxan monohydrate (SIGMA), glibenclamide (Kalbe Farma), ovalbumin (SIGMA), pellets are used to feed the mice, and tap water is used as a drink.

\section{Procedures}

Before the treatment, 45 mice Balb/c which are 2-3 months old and male with an average body weight of $35 \mathrm{~g}$, are acclimated to suit laboratory conditions, then they are divided into nine groups. They are fed with pellets and drink with tap water and ad libitum. Then the following works are performed:

Determination of dosage and injection of alloxan. Alloxan dose given to monkeys (Macaca fascicularis) after being converted to white rats weighing $200 \mathrm{~g}$ is $35 \mathrm{mg} / 200$ g BW (Widyastuti et al. 2005). For mice weighing $35 \mathrm{~g}$ is $35 / 200 \times 35 \mathrm{mg}=6.125 \mathrm{mg} / 35 \mathrm{~g} \mathrm{BW}$. For injection, the alloxan is dissolved in $0.5 \mathrm{~mL}$ of distilled water.

Determination of dosage and the oral application of glibenclamide. The dose of glibenclamide in humans is 5 $\mathrm{mg} /$ day/70 kg BW (Tjay and Rahardja 2007), then converted in mice $=35 / 70000 \times 5 \mathrm{mg}=0.00025 \mathrm{mg} /$ day $135 \mathrm{~g} \mathrm{BW}$ and for every application, it is dissolved with 0.5 CMC $1 \%$.

Determination of dosage and the application of VCO. VCO is given to the human therapeutic dose is generally three tablespoons or $45 \mathrm{~mL} /$ day (Dayrit, 2000); when converted in mice, it is $35 / 70.000 \times 45=0.00225 \mathrm{~mL} /$ day $135 \mathrm{~kg} \mathrm{BW}$. In this study, the doses are given in 2 variations, dose $\mathrm{I}=0.002 \mathrm{~mL} /$ day and dose $\mathrm{II}=0.003$ $\mathrm{mL} /$ day.

Determination of blood glucose levels. Blood glucose level was determined with the GOD-PAP method (Enzymatic Photometric Test), which is the method of photometric measurement with a spectrophotometer (Widowati et al. 1977). During the study, the measurements are taken six times: day 1 (just before alloxan treatment), day 4 , day 18 , day 22 , day 32 , and day 37 (just before the sacrifice).

Determination of dose and way of allergen injection. Determination of allergen dose and route of allergen injection refers to the work of Diding (2007), who managed to create mice with an average weight of $17.5 \mathrm{mg}$ to have an allergy on its digestive system. This study used mice with an average weight of $35 \mathrm{mg}$, so every injection can be converted into $2 \mathrm{X}$ of the initial dose, with the protocol as follows: On day 22, sensitization of mice by injection of $0.30 \mathrm{~mL}$ ovalbumin out of $2.5 \mathrm{mg}$ ovalbumin in $7.75 \mathrm{~mL}$ of $\mathrm{Al}(\mathrm{OH})_{3}$ in an intra-peritoneal way. The re-sensitization is with the same solution and the same way on day 28. then, on days 32-34 consecutively, the mice were re-sensitized by giving a solution of $0.30 \mathrm{~mL}$ ovalbumin of $2.5 \mathrm{mg}$ ovalbumin in $2.5 \mathrm{~mL}$ of PBS orally.

Preparations of blood smear and determination of leukocyte count using the Romanowski method. The blood is dropped on the surface of glass objects then made 
into smears/blood film. Furthermore, they are air-dried for a few minutes, and then they are dropped with methyl alcohol and left untouched for 5 minutes. Moreover, the preparations are lifted and placed in 1-2\% of Giemsa dye solution for 30 minutes. Finally, the preparations are removed from the dye solution, washed with water, and carefully dried with a tissue, and then they are ready to be observed under a microscope (Suntoro 1983). After all form of leukocytes is observed under a microscope with 10x100 magnification, with emersion oil paced on the surface of the smear preparations. Furthermore, the percentage of each type of leukocyte from 100 leukocytes found in every preparation is counted (Fox 1990).

Calculation of blood creatinine levels. A decrease in renal physiological function can be ascertained from the increased blood creatinine levels. Blood creatinine levels were measured with a spectrophotometer of a photometric system based on the method of Daffe.

\section{The experimental design}

This study used 45 mice (M. musculus Balb/c) divided into nine groups. The blood glucose measurements were performed six times, and then a Completely Randomized Design was carried out, using nine kinds of treatments with five replications at each treatment, as follows:

A. Treatment of normal controls: mice were given food and drank each day ad libitum without any treatment until the end of the study.

B. Treatment of non-alloxan, CMC, and ovalbumin sensitization: on day four, mice were given $0.5 \mathrm{~mL}$ of $1 \%$ CMC orally every day until the end of the study. Ovalbumin sensitization was started on days 22-36.

C. Non-alloxan treatment, the dose I of VCO and ovalbumin sensitization: on day four, mice were given orally with VCO $0.002 \mathrm{~mL} / 35 \mathrm{~g} \mathrm{BW}$ every day until the end of the study. Ovalbumin sensitization was started from days 22-36.

D. Treatment of non-alloxan, VCO dose II, and ovalbumin sensitization: on day four, mice were given orally with VCO $0.003 \mathrm{~mL} / 35 \mathrm{~g} \mathrm{BW}$ every day until the end of the study. Ovalbumin sensitization was started from days 22-36.

E. Treatment of hyperglycemia control: on day one, mice were injected with alloxan $6.125 \mathrm{mg} / 35 \mathrm{~g} \mathrm{BW}$ subcutaneous. They were then fed and drank ad libitum without any treatment until the end of the study.

F. Treatment of alloxan, CMC, and ovalbumin sensitization: on day one, mice were injected subcutaneously with alloxan $6.125 \mathrm{mg} / 35 \mathrm{~g} \mathrm{BW}$, then on day 4-36 were given $0.5 \mathrm{~mL}$ of $1 \%$ CMC. Ovalbumin-sensitized was begun on days 22-36.

G. Treatment of alloxan, VCO dose I, ovalbumin sensitization: mice were injected subcutaneously with $6.125 \mathrm{mg} / 35 \mathrm{~g} \mathrm{BW}$ on day one. On days 4-36, VCO $0.002 \mathrm{~mL} / 35 \mathrm{~g} \mathrm{BW}$ were given orally, and ovalbumin sensitization began on days 22-36.

H. Treatment of alloxan, VCO dose II, ovalbumin sensitization: on day one, mice were injected subcutaneously $6.125 \mathrm{mg} / 35 \mathrm{~g} \mathrm{BW}$, then on day 4-36 were given with $0.003 \mathrm{~mL} / 35 \mathrm{~g} \mathrm{BW}$ of VCO orally, and ovalbumin desensitization began on day 22-36.

I. Treatment of alloxan, glibenclamide, and ovalbumin sensitization: on day one, mice were injected subcutaneously with alloxan $6.125 \mathrm{mg} / 35 \mathrm{~g} \mathrm{BW}$, then on day 4-36 was given orally with $0.0025 \mathrm{mg}$ of glibenclamide in $1 \% \mathrm{CMC}$, and ovalbumin sensitization began on day 22-36.

\section{Data analysis}

Quantitative data of blood glucose levels were analyzed using the ANOVA (Analysis of Variance). If there are significant differences, it is followed by the DMRT test (Duncan's Multiple Range Test) at the significance level of $5 \%$ to determine the significant differences among the treatments. So, the VCO effect in decreasing the blood glucose levels in hyperglycemic mice can be detected. Quantitative data of leukocyte differential were obtained by counting each type of leukocyte in each treatment group. And then, the data mean were compared with a differential of normal leukocyte, according to Smith and Mangkoewidjojo (1988) and Jacoby and Fox (1984) to compare the leukocyte differential of mice in conditions of hyperglycemia, hyperglycemia that has been treated with the VCO, and hyperglycemia which is exposed to allergens, mice exposed to VCO which is then exposed to allergens and normal leukocyte differential in mice, so that can know the relationship between hyperglycemia, VCO and the development of allergy-immunology. Quantitative data average blood creatinine levels of each treatment group are compared with the normal rate according to Jacoby and Fox (1984), so the effect of VCO treatments on the functional status of renal physiology can be known.

\section{RESULTS AND DISCUSSION}

\section{Blood Glucose Levels (BGL)}

From the results, the state/condition of blood glucose levels data can be obtained as shown in Table 1 and Figure 1: the Mean of Blood Glucose Levels (BGL) of all treatment, measurement 1 to measurement 6, Figure 2: the Mean of BGL of non-alloxan groups, measurements 1 to 6 and, Figure 3: Mean BGL of alloxan groups, measurement 1 to 6 . The data obtained is analyzed by analysis of variance (ANOVA) one way. When there is a significant difference, it is followed by the Duncan test (DMRT) with a significance level of $5 \%$ to determine the real differences among the treatments.

On day one, the first average blood glucose level measurement was started just before alloxan injection. The mean blood glucose levels of 45 mice were classified into nine treatment groups. Figure 1 shows no significant differences in the blood glucose levels of all treatment groups from A to I. It means that between groups that were not given with alloxan and the group given with alloxan showed no significant difference, namely in a range of 61.40 to $71.80 \mathrm{mg} / \mathrm{dl}$. This is because all the mice used were in normal-glycemia and relatively similar. 
Table 1. Changes in average blood glucose level groups of mice during treatment

\begin{tabular}{|c|c|c|c|c|c|c|c|c|c|c|c|}
\hline \multirow{3}{*}{$\begin{array}{l}\text { Treatment } \\
\text { group }\end{array}$} & \multicolumn{11}{|c|}{ Blood glucose levels day by } \\
\hline & \multirow{2}{*}{$\begin{array}{c}\text { ( day-1) } \\
\mathrm{mg} / \mathrm{dl}\end{array}$} & \multicolumn{2}{|c|}{2 (day-4) } & \multicolumn{2}{|c|}{3 (day-18) } & \multicolumn{2}{|c|}{4 (day-22) } & \multicolumn{2}{|c|}{5 (day-32) } & \multicolumn{2}{|c|}{6 (day-37) } \\
\hline & & $\mathrm{mg} / \mathrm{dl}$ & $\%$ changes & $\mathrm{mg} / \mathrm{dl}$ & $\%$ changes & $\mathrm{mg} / \mathrm{dl}$ & $\%$ changes & $\mathrm{mg} / \mathrm{dl}$ & $\%$ changes & $\mathrm{mg} / \mathrm{dl}$ & $\%$ changes \\
\hline \multicolumn{12}{|c|}{ Non alloxan } \\
\hline A & $71,600^{\mathrm{a}}$ & $96,600^{\mathrm{abc}}$ & +34.9 & $108,600^{\mathrm{a}}$ & +51.7 & $119,000^{\mathrm{ab}}$ & +66.2 & $137,000^{\mathrm{ab}}$ & +91.3 & $69,000^{\mathrm{a}}$ & -3.6 \\
\hline B & $61,400^{\mathrm{a}}$ & $79,200^{\mathrm{ab}}$ & +29 & $110,000^{\mathrm{a}}$ & +79.2 & $82,000^{\mathrm{a}}$ & +33.6 & $78,800^{\mathrm{a}}$ & +28.3 & $92,800^{\mathrm{ab}}$ & +51 \\
\hline $\mathrm{C}$ & $67,200^{\mathrm{a}}$ & $66,400^{\mathrm{a}}$ & -1.2 & $93,200^{\mathrm{a}}$ & +38.7 & $75,200^{\mathrm{a}}$ & +12 & $86,400^{\mathrm{a}}$ & +28.6 & $101,600^{\mathrm{ab}}$ & +51.2 \\
\hline $\mathrm{D}$ & $61,400^{\mathrm{a}}$ & $124,200^{\mathrm{abc}}$ & +102 & $87,800^{\mathrm{a}}$ & +43 & $113,000^{\mathrm{ab}}$ & +84 & $79,400^{\mathrm{a}}$ & +29.3 & $97,200^{\mathrm{ab}}$ & +58.3 \\
\hline \multicolumn{12}{|l|}{ Alloxan } \\
\hline $\mathrm{E}$ & $69,600^{\mathrm{a}}$ & $159,000^{\mathrm{c}}$ & +128.4 & $157,800^{\mathrm{ab}}$ & +126.7 & $160,800^{\mathrm{bcd}}$ & +131 & $156,600^{\mathrm{ab}}$ & +125 & $179,200^{c}$ & +157.5 \\
\hline $\mathrm{F}$ & $71,800^{\mathrm{a}}$ & $142,000^{\mathrm{bc}}$ & +97.8 & $222,000^{\mathrm{bc}}$ & +209.2 & $128,000^{\mathrm{abc}}$ & +78.3 & $132,200^{\mathrm{ab}}$ & +84 & $150,200^{\mathrm{bc}}$ & +109 \\
\hline $\mathrm{G}$ & $67,200^{\mathrm{a}}$ & $158,800^{\mathrm{c}}$ & +136 & $338,000^{\text {de }}$ & +403 & $205,400^{\mathrm{d}}$ & +205.7 & $220,200^{b}$ & +227.7 & $230,200^{c}$ & +242.6 \\
\hline $\mathrm{H}$ & $64,400^{\mathrm{a}}$ & $122,800^{\mathrm{abc}}$ & +90.7 & $299,800^{\mathrm{cd}}$ & +365.5 & $168,200^{\mathrm{bcd}}$ & +161.2 & $104,200^{\mathrm{a}}$ & +61.8 & $200,200^{c}$ & +210.9 \\
\hline I & $61,800^{\mathrm{a}}$ & $298,800^{\mathrm{d}}$ & +383.5 & $413,600^{d}$ & +413.6 & $177,000^{\mathrm{cd}}$ & +186.4 & $162,200^{\mathrm{ab}}$ & +162 & $191,200^{c}$ & +209.4 \\
\hline
\end{tabular}

Note: The number followed the same superscript letter within a column indicate no significant difference between treatments ( $\mathrm{p}>0.05$ ). A: normal control group (non-alloxan, non-allergen), B: The treatment of non alloxan, CMC and allergens/ovalbumin, C: Treatment of non alloxan, VCO dose I and allergens/ovalbumin, D: Treatment of non alloxan, VCO II dose and allergen/ovalbumin, E: The control group alloxan/hyperglycemia (alloxan, non-allergen), F: The treatment of alloxan, CMC and allergens/ovalbumin, G: Treatment of alloxan, VCO dose and allergen/ovalbumin, H: Treatment of alloxan, VCO dose II and allergens/ovalbumin, I: Treatment alloxan, glibenclamide and allergens/ovalbumin.
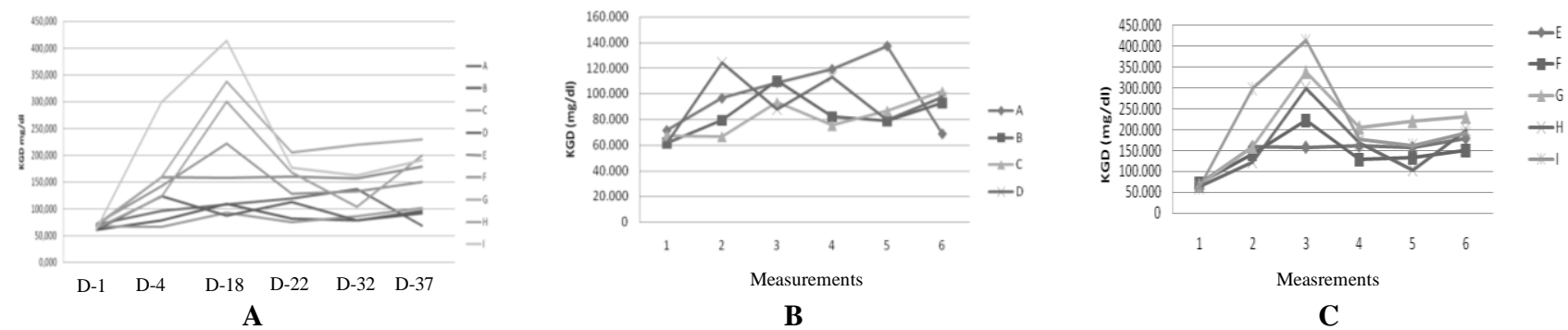

Figure 1. Blood Glucose Levels of 1 to 6 repeated measurement. A. All treatment, B. Non-alloxan measurement, C. Alloxan measurement. Note: Description of A to I are similar to Table 1.

Figure 1 shows measurement 2 (day 4); all treatment groups, given alloxan or not, increased blood glucose levels, although the nonalloxan groups were not statistically significant compared to levels at the beginning of treatment. The increase in nonalloxan groups allegedly was due to stress because of the treatment of grouping in a different cage from its usual cage. Stress conditions will stimulate the sympathetic nervous system for the adrenal medulla to secrete the epinephrine hormone, which causes the increase in blood glucose levels (Guyton and Hall 2008). Mice experienced the same in the groups treated with alloxan.

In the $3^{\text {rd }}$ measurement (day 18), nonalloxan groups have blood glucose levels that can be stable, i.e., an average maximum of about $100 \mathrm{mg} / \mathrm{dl}$. The difference with the alloxan group so contrasts. This is because they all had an increase in blood glucose levels significantly.

On day 1 , shortly after measuring blood glucose levels, the groups were treated with alloxan. Alloxan plays a role in pancreatic beta cells that produce insulin and selectively kill these cells (Suharmiati 2003; Guyton and Hall 2008). The destruction of pancreatic beta cells causes the quantity and or quality of insulin, disturbing the smooth transport of glucose from the blood into the tissues; it causes the glucose to pile up in the blood, causing an increase in levels (hyperglycemia).

In the $4^{\text {th }}$ measurement (day 32), the average blood glucose level of groups of mice induced with alloxan had a significant reduction. The same blood glucose levels were found in group H (alloxan, VCO dose II, ovalbumin) and group I (alloxan, glibenclamide, ovalbumin). However, it did not reach the previous level, which was not significantly different from the level in the initial treatment, but giving a dose of VCO 2 after 18 days gives the same effect as the provision of glibenclamide, which lowers blood glucose levels. According to Tjay and Rahardja (2007), glibenclamide is one oral antidiabetic drug, including sulfonylurea. Sulfonylurea drugs play a role in stimulating the beta cells of Langerhans islands to increase insulin secretion; besides, they can also increase the sensitivity of beta cells for blood glucose levels through their influence on glucose transport proteins. There are indications that these drugs also improve the target organ of insulin and decrease the absorption of insulin by the liver. While in group H (alloxan, VCO dose II, ovalbumin), a decline in blood glucose levels happened after the oral 
provision of $\mathrm{VCO}$ at a dose of $0.003 \mathrm{~mL} / 35 \mathrm{~g} \mathrm{BW}$ every day for 18 days. This was because the VCO improves metabolic activity. MCFAs in the VCO, which are monolauric, can reduce protein catabolism in hypercatabolic states. They can serve as a protein sparer that prevents oxidation of amino acids from producing energy and provides protein into the tissues. The supply of network protein stimulates the secretion of glucagon, which activates adenyl cyclase that will produce cyclic AMP, so the phosphorylation for the processes of normal cell metabolism is activated, such as the repairing of gland secretion and enzymes activity, hormones, and of their receptors (Guyton and Hall 2008). In this case, it is assessed that there was an increase in insulin sensitivity hormones and tissues of the insulin receptor, so the supply of glucose into the tissue was normal. The other insulin functions are also normal so that high blood glucose levels could be lowered.

In group G (alloxan, VCO dose I, ovalbumin), the same mechanism with group $\mathrm{H}$ (alloxan, VCO dose II, ovalbumin) occurred through the decrease was not as much as a dose of VCO 2 group. The mechanism was assumed to be the same. In the normal group or the control solvent, decreased blood glucose levels occurred, although no substance could act as healers, including group E (alloxan, non-therapeutic, non-ovalbumin) and group $\mathrm{F}$ (alloxan, CMC, ovalbumin). This was due to the recovery levels of the hormone epinephrine in experimental mice as the body's response to restore its normal conditions. Therefore, $1 \%$ CMC solution was only used as a hydrophilic gel drug compound that was nontoxic. It was not digested and not absorbed by the individual (Tjay and Rahardja 2007), so it does not affect changes in blood glucose levels. Only the $\mathrm{H}$ group (alloxan, VCO dose II, and ovalbumin) is steadily declining blood glucose levels until day $32^{\text {nd }}$ but rose again on day $37^{\text {th }}$ after ovalbumin sensitization protocol is complete. This is because, despite improved metabolic activity with the $\mathrm{VCO}$, due to the body's response to ovalbumin, which acts as allergens, blood glucose levels increased because of damage to pancreatic beta cells selectively, were damaged again, although not fatal.

In groups of non-alloxan, the rise of blood glucose levels that occurred is assumed because of stress. The decline did not happen simultaneously; it was because the body's response to restore normal conditions of each group was also influenced by the initial conditions and the given therapeutic as well as the body's response to allergens given. Three non-alloxan groups except group A (nonalloxan, non-therapeutic, non-ovalbumin) decreased maximally. They reached levels that were not significantly different from day $32^{\text {nd }}$, Groups $\mathrm{C}$ and $\mathrm{D}$, which were given $\mathrm{VCO}$, had been reduced first due to improved metabolic activity. In group A, a new decline occurred on day $32^{\text {nd }}$ and continued to decline because there was no influence in the body, including allergens.

\section{Determination of leukocyte differential}

Data on the average percentage of each leukocyte type of all treatment groups are shown in Table 2. Data average percentage of each leukocyte type of each treatment group is compared to its normal standard of mice according to Smith and Mangkoewidjojo (1988) and according to Jacoby and Fox (1984).

On day one, the first average blood glucose level measurement was started just before alloxan injection. The mean blood glucose level of 45 mice was classified into nine treatment groups. Figure 1 showed no significant differences in the blood glucose levels of all treatment groups from A to I. It means that between groups that were not given with alloxan and the group given with alloxan showed no significant difference, namely in a range of 61.40 to $71.80 \mathrm{mg} / \mathrm{dl}$. This is because all the mice used were normal-glycemic and relatively similar.

Figure 1 shows measurement 2 (day 4); all treatment groups, given alloxan or not, increased blood glucose levels, although the nonalloxan groups were not statistically significant compared to levels at the beginning of treatment. The increase in nonalloxan groups allegedly was due to stress because of the treatment of grouping in a different cage from its usual cage. Stress conditions stimulated the sympathetic nervous system for the adrenal medulla to secrete the epinephrine hormone, which caused the increase in blood glucose levels (Guyton and Hall 2008). Mice experienced the same in the groups treated with alloxan.

In the $3^{\text {rd }}$ measurement (day 18), nonalloxan groups had blood glucose levels that can be said to be stable, i.e., an average maximum of about $100 \mathrm{mg} / \mathrm{dl}$. The difference with the alloxan group so contrasts. This is because they all had an increase in blood glucose levels significantly.

On day 1 , shortly after measuring blood glucose levels, the groups were treated with alloxan. Alloxan plays a role in pancreatic beta cells that produce insulin and selectively kill these cells (Suharmiati 2003; Guyton and Hall 2008). The destruction of pancreatic beta cells causes the quantity and or quality of insulin, disturbing the smooth transport of glucose from the blood into the tissues; it causes the glucose to pile up in the blood, causing an increase in levels (hyperglycemia).

In the $4^{\text {th }}$ measurement (day 32), the average blood glucose level of groups of mice induced with alloxan had a significant reduction. The same blood glucose levels are found in group $\mathrm{H}$ (alloxan, VCO dose II, ovalbumin) and group I (alloxan, glibenclamide, ovalbumin). However, it does not reach the previous level, which is not significantly different from the level in the initial treatment; giving a dose of VCO 2 after 18 days gives the same effect as the provision of glibenclamide, which lowers blood glucose levels. According to Tjay and Rahardja (2007), glibenclamide is one oral antidiabetic drug, including sulfonylurea. Sulfonylurea drugs play a role in stimulating the beta cells of Langerhans islands to increase insulin secretion; besides, they can also increase the sensitivity of beta cells for blood glucose levels through their influence on glucose transport proteins. There are indications that these drugs also improve the target organ of insulin and decrease the absorption of insulin by the liver. While in group H (alloxan, VCO dose II, ovalbumin), a decline in blood glucose levels happened after the oral provision of $\mathrm{VCO}$ at a dose of $0.003 \mathrm{~mL} / 35 \mathrm{~g} \mathrm{BW}$ every day for 18 
days. This is because the VCO improves metabolic activity. MCFAs in the VCO, which are monolauric, can reduce protein catabolism in hypercatabolic states. They can serve as a protein sparer that prevents the oxidation of amino acids from producing energy. They can also provide protein into the tissues. The supply of network protein stimulates the secretion of glucagon, which activates adenyl cyclase that will produce cyclic AMP, so the phosphorylation for the processes of normal cell metabolism is activated, such as the repairing of gland secretion and enzymes activity, hormones, and of their receptors (Guyton and Hall 2008). In this case, it is assessed that there was an increase in insulin sensitivity hormones and tissues of the insulin receptors, so the supply of glucose into the tissue was normal. The other insulin functions were also normal to lower high blood glucose levels.

In group G (alloxan, VCO dose I, ovalbumin), the same mechanism with group $\mathrm{H}$ (alloxan, VCO dose II, ovalbumin) occurred through the decrease was not as much as a dose of VCO 2 group. The mechanism is assumed to be the same. In the normal group or the control solvent, decreased blood glucose levels occurred, although no substance could act as healers, including group E (alloxan, non-therapeutic, nonovalbumin) and group F (alloxan, CMC, ovalbumin). This is due to the recovery levels of the hormone epinephrine in experimental mice as the body's response to restore its normal conditions. Therefore, $1 \%$ CMC solution was only used as a nontoxic hydrophilic gel drug compound. It was not digested and was not absorbed by the individual (Tjay and Rahardja 2007), so it does not affect changes in blood glucose levels. Only the $\mathrm{H}$ group (alloxan, VCO dose II, and ovalbumin) is steadily declining blood glucose levels until day $32^{\text {nd }}$ but rose again on day $37^{\text {th }}$ after ovalbumin sensitization protocol is complete. This is because, despite improved metabolic activity with the VCO, due to the body's response to ovalbumin, which acts as allergens, blood glucose levels increased because of damage to pancreatic beta cells selectively, were damaged again, although not fatal.

In groups of nonalloxan, the rise of blood glucose levels that occurred is assumed because of stress. The decline did not happen simultaneously; it was because the body's response to restore normal conditions of each group was also influenced by the initial conditions and the given therapeutic as well as the body's response to allergens given. Three non-alloxan groups except group A (nonalloxan, non-therapeutic, non-ovalbumin) decreased maximally. They reached levels that were not significantly different from day $32^{\text {nd }}$, Groups $\mathrm{C}$ and $\mathrm{D}$, which were given $\mathrm{VCO}$, had been reduced first due to improved metabolic activity. In group A, a new decline occurred on day $32^{\text {nd }}$ and continued to decline because there is no influence in the body, including allergens.

The differential of leukocytes of group A as control (non-alloxan, non-therapeutic, non-ovalbumin) was: $1.140 \%$ of neutrophils; $90.76 \%$ of lymphocytes, $1.52 \%$ of monocytes, $0.22 \%$ of eosinophils, and $3.00 \%$ of basophils. All percentage of neutrophile of groups with treatment is less than the normal standard by Smith and
Mangkoewidjojo (1988) and/or according to Jacoby and Fox (1984), except in group H (alloxan, VCO $0.003 \mathrm{~mL} / \mathrm{g}$ BW, ovalbumin), which has a normal percentage. Furthermore, all lymphocyte percentage of groups with treatment is high above normal standards according to Smith and Mangkoewidjojo (1988) and/or according to Jacoby and Fox (1984), except in group F, which has a normal percentage. All the percentage of monocytes is normal, except in group D (non-alloxan, VCO $0.003 \mathrm{~mL} / \mathrm{g}$ $\mathrm{BW})$, most of the eosinophils percentage in groups with treatment is less than the normal percentage. The percentage of basophils is higher than normal standards, except for groups C, D, E, G, H, and I.

From the above data, it is estimated that there has been an immunological defense mechanism in animal studies, which is likely due to a viral infection. Because according to Burkitt et al. (1995), an increased number of lymphocytes is generally a marking of a viral infection. The neutrophil percentage is far below the percentage of normal; it also supports the allegation. According to Price and Wilson (2006), neutropenia can be caused by disorders of neutrophil formation or the formation of ineffective neutrophil due to hypoplastic or aplastic anemia caused by cytotoxic drugs, the presence of toxic substances and viral infections, starvation, and replacement by normal bone marrow by malignant cells, as in leukemia since lymphocytes have a central role in all immunological defense mechanisms. The increasing percentage of basophils is supposed to be due to the induction of sensitized lymphocytes to respond to antigens or environmental allergens that are less profitable. According to Price and Wilson (2006), basophils and mast cells have a membrane receptor typical for this segment of Fc \& IgE produced by plasma cells as antigen/allergen environment. Burkitt et al. (1995) also state that basophils are responsible primarily for giving an allergic reaction and antigen by releasing chemicals histamine that causes inflammation. According to the authors, the high percentage of basophils in these groups responds to environmental antigens that arise due to endogenous viruses that infected them. The percentage of neutrophil on group $\mathrm{H}$ (alloxan, VCO 0.003 $\mathrm{mL} / \mathrm{g} \mathrm{BW}$, ovalbumin) occupies the normal range according to Smith and Mangkoewidjojo (1988) or by Jacoby and Fox (1984)

In the study, mice groups were suspected of suffering from a viral infection, but with the consumption of VCO, the reduction of virus amount is assumed to occur because of the MCFAs role, mainly monolaurin, through its lipid membrane, so the percentage of its neutrophil is normal, and this will improve the immunologic status of these mice groups. These groups also had a normal percentage of basophils. Basophils are primarily responsible for allergic reactions and histamine release by antigen chemical that causes inflammation. Basophils and mast cells have a specific membrane for the segment of $\mathrm{IgE}$ and $\mathrm{Fc}$, which is generated by cells' plasma to respond to several environmental allergens. Exposure of allergens causes the formation of bridges between the adjacent $\operatorname{IgE}$ molecules that appropriately trigger the evisceration of granule/degranulation. So, the release of histamine and 
Table 2. The mean percentage of the types of leukocytes from all groups of Mus musculus (mice), day 37 (last day of the study) after treatment of a variety of healers and ovalbumin sensitization

\begin{tabular}{|c|c|c|c|c|c|}
\hline \multirow{2}{*}{ Treatment group } & \multicolumn{5}{|c|}{ Number of cells (\%) } \\
\hline & Neutrophils & Lymphocytes & Monocytes & Eosinophils & Basophils \\
\hline \multicolumn{6}{|l|}{ Non alloxan } \\
\hline A & $1.140^{--}$ & $90.760^{++}$ & $1.520^{*}$ & $0.220^{*}$ & $3.000^{++}$ \\
\hline B & $4.460^{--}$ & $88.920^{+}$ & $0.920^{*}$ & $0.520^{*}$ & $3.760^{++}$ \\
\hline $\mathrm{C}$ & $1.580^{--}$ & $95.580^{++}$ & $1.920^{*}$ & $0.200^{*}$ & $0.480^{*}$ \\
\hline $\mathrm{D}$ & $2.600^{--}$ & $93.580^{++}$ & $4.580^{++}$ & $0.060^{-}$ & $0.760^{*}$ \\
\hline \multicolumn{6}{|l|}{ Alloxan } \\
\hline $\mathrm{E}$ & $3.220^{-}$ & $94.540^{++}$ & $0.820^{*}$ & $0.260^{*}$ & $0.460^{*}$ \\
\hline $\mathrm{F}$ & $5.480^{-}$ & $82.120^{*}$ & $1.420^{*}$ & $0.140^{-}$ & $6.420^{++}$ \\
\hline $\mathrm{G}$ & $0.860^{--}$ & $95.460^{++}$ & $1.180^{*}$ & $0.200^{*}$ & $0.060^{*}$ \\
\hline $\mathrm{H}$ & $10.100^{*}$ & $85.800^{+}$ & $1.200^{*}$ & $0.120^{-}$ & $0.580^{*}$ \\
\hline I & $0.820^{--}$ & $97.720^{++-}$ & $1.420^{*}$ & $0.140^{-}$ & $0.240^{*}$ \\
\hline \multicolumn{6}{|l|}{ Standard normal } \\
\hline J & $12-30$ & $55-85$ & $1-12$ & $0.2-4.0$ & - \\
\hline $\mathrm{K}$ & $6.7-37.2$ & $63-75$ & $0.7-2.6$ & $0.9-3.8$ & $0-1.5$ \\
\hline
\end{tabular}

Note: Description of A to I are similar to Table 1. J. The normal according to Smith dan Mangkoewidjojo (1988). K. J. The normal according to Jacoby and Fox (1984). +: Greater than normal according to Smith and Mangkoewidjojo (1988) / Jacoby and Fox (1984) or both. -: Smaller than normal according to Smith and Mangkoewidjojo (1988) / Jacoby and Fox (1984) or both. *: Fulfilling the normal range according to Smith and Mangkoewidjojo (1988) / Jacoby and Fox (1984) or both.

other vasoactive mediators is responsible for the occurrence of acute hypersensitivity reactions to allergic rhinitis (hay fever), some forms of asthma, urticaria, and anaphylactic shock. But, there are other incentives for the occurrence of $\operatorname{IgE}$ independent mast cell degranulation. Basophils also represent $15 \%$ of infiltrating cells in allergic dermatitis, and skin allograft rejection, known as basophils skin hypersensitivity, is induced by sensitized lymphocytes and is a kind of hypersensitivity with media of slow degranulation cells (Burkitt et al. 1995).

Because the MCFAs in the VCO are particularly monolaurin, which can reduce protein catabolism in hypercatabolic status and serve as a protein sparer that prevents oxidation of amino acids from producing energy, it supplies the protein into tissue. The supply of tissue protein stimulates glucagon secretion, which activates adenyl cyclase, creating cyclic AMP; so, the phosphorylation for cell metabolism processes is activated normally, such as gland secretion and activity of enzymes, hormones, or repairing their receptors (Guyton and Hall 2008). The repair of hormones activity increases the sensitivity of receptors that they will have the ability to actively induce immunological response toward the Th1Th2 balance after being exposed to ovalbumin allergen. According to Endaryanto and Harsono (1996), allergic is a form of Th2 disease in which cure requires the patient to be on a balanced condition between Th1 and Th2. So, if risk factors cannot be avoided for the prevention, active induction of immunological response toward Th1-Th2 balance needs to have strived. According to Abbas and Lichtman (2004), allergy is a type of pathological reaction caused by releasing mediators from mast cells. Generally, the production of IgE antibody cells mast is in various body tissues. The situation is followed by inflammation in some individuals exposed to specific foreign antigens which have hit them before. Basically, the immune response is to act protectively, whether specific or nonspecific. But the immune response can lead to bad consequences and even a disease called hypersensitivity. In addition, according to Bratawidjaja (2004), levels of cAMP and cGMP in cells affect the degranulation of mast cells. The increase of cAMP prevents degranulation, while the moderate increase in cGMP boosts the prevention. So normally, the percentage of basophils is in the groups protected by VCO; although they were sensitized with ovalbumin, they allegedly did not experience an allergic event; this was due to the prevention of degranulation of basophils due to the increase in AMP cyclic caused by the provision of VCO.

The role of monocytes and eosinophils are not explicitly needed on this group because this study allegedly has no relation to bacteria, and the given ovalbumin gives no result in an anaphylactic reaction. According to Burkitt et al. (1995), the role of eosinophils is, among others, to destroy parasites, to respond to bacterial products, and as complement components, especially a substance released by basophils, namely histamine and eosinophil chemotactic factor of anaphylaxis other than activated lymphocytes, the percentage of eosinophils in this group which was just below normal indicates high rates balance toward a percentage of lymphocytes.

\section{Measurements of blood creatinine levels}

The average blood creatinine levels of each group are presented in Table 3. The data is then compared with the normal creatinine levels in mice by Jacoby and Fox (1984). From the measurement results of 9 groups of mice, it was found that all groups had a magnitude of blood creatinine levels between 0.320 to $0.5040 \mathrm{mg} / \mathrm{dl}$, which still meet the range of normal numbers by Jacoby and Fox (1984), namely 0.21 to $0.74 \mathrm{mg} / \mathrm{dl}$. 
Table 3. Mean blood creatinine levels of all treated groups on day 37 (end of study)

\begin{tabular}{lc}
\hline Treatment group & Blood creatinine levels $(\mathbf{m g} / \mathbf{d l})$ \\
\hline Nonalloxan & \\
A & 0.3760 \\
B & 0.4080 \\
C & 0.4040 \\
D & 0.4200 \\
Alloxan & \\
E & 0.5040 \\
F & 0.4400 \\
G & 0.3200 \\
H & 0.4020 \\
I & 0.3900 \\
Standard normal & $0.21-0.74$ \\
J
\end{tabular}

Note: Description of A to I are similar to Table 1. J. The normal, according to Jacoby and Fox (1984).

Giving VCO with a dose of $0.002 \mathrm{~mL} / 35 \mathrm{~g} \mathrm{BW}$ and $0.0030 \mathrm{~mL} / 35 \mathrm{~g} \mathrm{BW}$ orally for 34 days (started on day $4^{\text {th }}$ $37^{\text {th }}$ ) is intended to lower blood glucose levels for groups of hyperglycemia mice and to protect the body against allergic reactions for groups of normoglycemia mice or groups that hyperglycemia does not affect the increase in blood creatinine levels. The increased creatinine value would indicate a decrease in excretion, for example, due to the decline in kidney function. Thus, plasma creatinine values which are still within the normal range after long-term consumption of this VCO, do not damage the kidneys; therefore, it is safe for consumption even though for longterm consumption. This is appropriate with Kabara's opinion (1978) that after consumption, the high percentage of lauric acid contained in the VCO, a medium-chain saturated fat, will come into the digestive tract and be readily absorbed without enzymatic process, thus more quickly reaching the bloodstream. Furthermore, through blood flow, it is brought to the liver (heart) and other tissues directly into mitochondria without the need for carnitine, and then will be converted into energy (ATP), so it will not be accumulated as fat that can lead to problems of blood vessels, etc. Lauric acid is the most important fatty acid in VCO, potentially building and maintaining the immune system. According to him, coconut oil improves the immune system, among others, by lowering the amount of $\mathrm{H} 4$ virus and increasing the number of CD4 cells without the side effects that are concluded from various clinical tests, among others, the number of blood cells, liver function tests (ALT and AST), renal function tests (urea and creatinine), blood lipids (cholesterol, triglycerides, HDL) and body weight.

\section{CONCLUSION}

Giving VCO (Virgin Coconut Oil) $0.003 \mathrm{~mL}$ per oral after 18 days can lower blood glucose levels of Mus musculus Balb/c with hyperglycemia. In this study, the leukocyte differential of mice with hyperglycemia: $3.220 \%$ of neutrophils, lymphocytes: $94.540 \%, 0.820 \%$, of monocytes, eosinophils: $0.260 \%, 0.460 \%$ of basophile, which reflects the low percentage of neutrophil and the high percentage of lymphocytes. Giving VCO onto differential of mice leukocytes exposed to ovalbumin will normalize the percentage of basophils. Giving VCO to the differential of hyperglycemic mice leukocyte which is exposed to ovalbumin can normalize the percentage of basophils and neutrophils.

\section{REFERENCES}

Abbas AK, Lichtman AH. 2004. Hypersensitivity Disease, Basic Immunology. 2nd ed. Saunders. Philadelphia.

Alba-Loureiro TC, Hirabara SM, Mendonça JR, Curi R, Pithon-Curi TC. 2006. Diabetes causes marked changes in the function and metabolism of rat neutrophils. J Endocrinol 188 (2): 295-303. DOI: 10.1677 joe. 1.06438

Bratawidjaja KG. 2004. Basic Immunology. Faculty of Medicine, Universitas Indonesia, Jakarta. [Indonesian]

Burkitt HG, Young B, Heath JW. 1995. Handbook and Atlas of Wheater functional histology. In: Tambayong J, Melfiawati S (eds). EGC. Jakarta. [Indonesian]

Caradang EV. 2005. Health benefits of virgin coconut oil explained. Philippine Coconut Research and Development Foundation (PCRDF). Manila.

Dayrit C. 2000. Coconut oil in health and disease's potential, it's and monolaurin's potential as cure for HIV/AIDS. 36th Cocotech Meeting, Chennai India, July 25, 2000.

Diding HP. 2007. Effect of probiotics on cytokine profiles and expression of TOOL LIKE receptor of intestinal mucosa of mice Balb/c allergen model. Faculty of Medicine, Sebelas Maret University. Surakarta. [Indonesian]

Endaryanto A, Harsono A. 1996. The prospect of probiotics in allergy prevention through the active induction of immunological tolerance. Faculty of Medicine, Airlangga University/RSUP Dr. Sutomo. Surabaya. [Indonesian]

Fife B. 2003. The healing miracles of coconut oil. Healthwise Pub. Colorado Springs.

Fox SI. 1990. A Laboratory Guide to Human Physiology (Concept Clinical Applications). 4th ed. Macmillan, New York.

Guyton A, Hall JE. 2008. Textbook of Medical Physiology. 11st ed. Elsevier, New York.

Hessel EM, Van Oosterhout AJ, Hofstra CL, De Bie JJ, Garssen J, Van Loveren H, Verheyen AK, Savelkoul HF, Nijkamp FP. 1995. Bronchoconstriction and airway hyperresponsiveness after ovalbumin inhalation in sensitized mice. Eur J Pharmacol 293 (4): 401-412. DOI: 10.1016/0926-6917(95)90061-6.

Jacoby RO, Fox JG. 1984. Biology and Disease of Mice. Academic Press. Orlando. DOI: 10.1016/B978-0-12-263620-2.50009-4.

Kabara JJ. 1984. Antimicrobial agents derived from fatty acids. J Am Oil Chem Soc 61 (2): 397-403. DOI: 10.1007/BF02678802.

Kresno SB. 2001. Imunologi: diagnosis dan prosedur laboratorium. Faculty of Medicine, University of Indonesia. Jakarta. [Indonesian]

Nugroho AE. 2000. Experimental animals with diabetes mellitus: pathology and mechanism of diabetogenic action. Biodiversitas 7 (4): 387-391. DOI: 10.13057/biodiv/d070415.

Otton R, Mendonca JR, Curi R. 1999. Diabetes causes marked changes in lymphocyte metabolism. J Endocrinol 174 (1): 55-61. DOI: 10.1677/joe.0.1740055.

Otton R, Soriano FG, Verlengia R, Curi R. 2004. Diabetes induces apoptosis in lymphocytes. J Endocrinol 182 (1): 145-156. DOI: 10.1677/joe.0.1820145.

Price SA, Wilson LM. 2006. Pathophysiology: Clinical Concept of Disease Processes. 6th ed. Elsevier. New York.

Smith JB, Mangkoewidjojo S. 1988. Pemeliharaan, Pembiakan dan Penggunaan Hewan Percobaan di Daerah Tropis. UI-Press, Jakarta. [Indonesian]

Suharmiati. 2003. Tests for anti-diabetes mellitus bioactivity of medicinal plants. Cermin Dunia Kedokteran 140: 8-13. [Indonesian]

Suntoro SH. 1983. Staining Method pewarnaan. Bhratara Karya Aksara. Jakarta. [Indonesian]

Tjay TH, Rahardja K. 2007. Essential Medicines: Efficacy, Usage, and Side Effects. $6^{\text {th }}$ ed. Elex Media Komputindo, Jakarta. [Indonesian]

UK Prospective Diabetes Study (UKPDS) Group. 1999. Intensive blood glucose control with sulphonylureas or insulin compared with conventional treatment and risk of complication in patient with type 2 diabetes. Lancet 352 (9131): 837-853. DOI: 10.1016/S0140-6736(98)07019-6.

Unger RH, Foster DW. 1992. Diabetes mellitus. In: Wilson JD, Foster DW. Endocrinology. W.B. Saunders, London.

Widowati L, Dzulkarnain B, Sa'roni. 1997. Medicinal plants for diabetes mellitus. Cermin Dunia Kedokteran 116: 53-60. [Indonesian]

Widyastuti SK, Ungerer T, Mansyoer I, Lelana RP. 2005. Long-tailed macaques (Macaca fascicularis) as a model of diabetes mellitus: effect of hyperglycemia on blood lipids, nitric oxide serum, and clinical behavior. J Veteriner 2 (2): 1-5. [Indonesian] 